\title{
Long-Term Grazing Effects on Genetic Variability in Mountain Rough Fescue
}

\author{
Yong-Bi Fu, ${ }^{1}$ Don Thompson, ${ }^{2}$ Walter Willms, ${ }^{3}$ and Mairi Mackay ${ }^{4}$ \\ Authors are ${ }^{1}$ Research Scientist, Plant Gene Resources of Canada, Saskatoon Research Centre, Agriculture and Agri-Food Canada, \\ 107 Science Place, Saskatoon, Saskatchewan, Canada, S7N 0X2; ${ }^{2}$ Research Scientist, Agriculture and Agri-Food Canada, \\ Kamloops Range Research Unit, 3015 Ord Rd, Kamloops, British Columbia, Canada, V2B 8A9; ${ }^{3}$ Research Scientist, \\ Agriculture and Agri-Food Canada, PO Box 3000, Lethbridge, Alberta, Canada, T1J 4B1; and ${ }^{4}$ Professor, Department of Biological Sciences, \\ University College of the Cariboo, 900 McGill Road, Kamloops, British Columbia, Canada, V2C 5N3.
}

\begin{abstract}
Festuca campestris Rydb. (mountain rough fescue) is a dominant grass species in the montane grasslands of western Canada. Little is known about the genetic diversity of this plant and the effects of long-term grazing on the genetics of populations. The amplified fragment length polymorphism (AFLP) technique was applied to compare the genetic diversity of fescue plants at adjacent grazed and protected areas for 3 populations spread across a longitudinal range: Stavely in the foothills, Milroy in the Rocky Mountain trench, and Goose Lake on the interior plateau. Five AFLP primer pairs were used to screen the tiller samples of about 39 plants in each grazed (or ungrazed) area, and 139 polymorphic AFLP bands were scored for each individual sample. These scored bands had frequencies ranging from 0.03 to 0.98 with an average of 0.56 . About $81 \%$ of the total AFLP variation resided within the populations. The Goose Lake population had the lowest level of AFLP variation, but genetically was the most distinct. Four AFLP bands were possibly associated with chromosomal segments significant for grazing resistance. Comparisons of AFLP variation between grazing and nongrazing samples revealed variable and relatively small impacts of the long-term grazing on the genetic diversity of the grazed populations. The AFLP variation of grazed samples was $1.5 \%$ lower at Goose Lake, 2.2\% higher at Milroy, and not different at Stavely. If developing diverse germplasm for rangeland seedings is desired, one should sample across geographic space rather than combining materials with and without historical grazing pressure.
\end{abstract}

\section{Resumen}

Festuca campestris Rydb. ("Mountain rough fescue") es una especie de gramínea dominante de los pastizales montañosos del oeste de Canadá. Poco se sabe acerca de la diversidad genética de esta planta y los efectos del apacentamiento a largo plazo sobre la genética de las poblaciones. Se aplicó la técnica de polimorfismo de la longitud de los fragmentos amplificados (AFLP) para comparar la diversidad genética de plantas de "Fescue" de áreas adyacentes apacentadas y sin apacentar (protegidas) para tres poblaciones distribuidas a lo largo de un gradiente longitudinal: Stavely en el pie de la montaña, Milroy en la trinchera de las Montañas Rocallosas y Goose Lake en la meseta interior. Cinco pares de primers AFLP fueron usados para examinar las muestras de hijuelos de aproximadamente 39 plantas de cada área, apacentada y sin apacentar y en cada muestra individual 139 bandas polimórficas AFLP fueron calificadas. Estas bandas calificadas tuvieron frecuencias que variaron de 0.03 a 0.98 , con un promedio de 0.56 . Aproximadamente $81 \%$ de la variación total de AFLP residió dentro de las poblaciones. La población de Goose Lake tuvo el menor nivel de variación de AFLP, pero genéticamente fue la mas distinta. Cuatro bandas AFLP posiblemente estuvieron asociadas con segmentos cromosómicos significativos para la resistencia al apacentamiento. Comparaciones de la variación de AFLP entre muestras apacentadas y no apacentadas revelaron impactos, variables y relativamente pequeños, del apacentamiento de largo plazo en la diversidad genética de las poblaciones apacentadas. La variación de AFLP de las muestras apacentadas fue 1.5\% más bajo en Goose Lake, 2.2\% más alto en Milroy y si diferencia en Stavely. Si se desea desarrollar germoplasma diverso para siembras de pastizales, uno debe muestrear a través del espacio geográfico en lugar de combinar materiales con y sin historial de presión de apacentamiento.

Key Words: native grass, Festuca campestris, cattle grazing, genetic diversity, AFLP

\section{INTRODUCTION}

Festuca campestris Rydb. (mountain rough fescue) is a grass with a caespitose growth form, having only basal leaves and few flowering tillers (Aiken and Darbyshire 1990). It occurs in the foothills of the Rocky Mountains in Alberta and Montana and in the river valleys and interior plateau of southern British

Correspondence: Yong-Bi Fu, Plant Gene Resources of Canada, Saskatoon Research Centre, Agriculture and Agri-Food Canada, 107 Science Place, Saskatoon, Saskatchewan, Canada, S7N 0X2. Email: fuy@agr.gc.ca

Manuscript received 14 February 2005; manuscript accepted 29 July 2005.
Columbia and northern Washington. This grass is highly productive, but it can lose vigor rapidly if heavily grazed during the growing season (Willms et al. 1985). For example, the plant density was 0.8 plants $\cdot \mathrm{m}^{-2}$ in a heavily grazed paddock and 1.4 plants $\cdot \mathrm{m}^{-2}$ in a less heavily grazed paddock (W. Willms, unpublished data, 2004). Thus, grazing may have generated selection pressure.

Investigations of grazing effects in grazed populations have focused more on morphological, physiological, and reproductive adaptations (e.g., Caldwell et al. 1981; Hodgkinson and Williams 1983; Kalkner and Casler 2000), and less on genetic variability and structure of grass populations (Carman and Briske 1985; Tomás et al. 2000; Matlaga and 
Table 1. Descriptions of the grazed and protected areas for 3 sites selected for sampling Festuca campestris Rydb. populations.

\begin{tabular}{|c|c|c|}
\hline \multirow[b]{2}{*}{ Site } & \multicolumn{2}{|r|}{ Area } \\
\hline & Protected & Grazed \\
\hline $\begin{array}{l}\text { Goose Lake, British } \\
\text { Columbia (lat } 50^{\circ} 6^{\prime} \mathrm{N} \text {, } \\
\text { long } 120^{\circ} 26^{\prime} \mathrm{W} ; \\
\text { elevation } 1160 \mathrm{~m} \text { ); } \\
\text { established in } 1931\end{array}$ & F. campestris Rydb. & $\begin{array}{l}\text { F. campestris with } \\
\text { reduced vigor; Stipa } \\
\text { columbiana Macoun; } \\
\text { Poa sandbergii Vasey; } \\
\text { Pseudoroegneria spicata } \\
\text { [Pursh] A. Love }\end{array}$ \\
\hline $\begin{array}{l}\text { Milroy, British Columbia } \\
\text { (lat } 49^{\circ} 53^{\prime} \mathrm{N} \text {, long } \\
115^{\circ} 44^{\prime} \mathrm{W} \text {; elevation } \\
830 \mathrm{~m} \text { ); established } \\
\text { in } 1950\end{array}$ & $\begin{array}{l}\text { F. campestris; } \\
\text { Festuca idahoensis } \\
\text { Elmer; P. spicata }\end{array}$ & $\begin{array}{l}\text { F. campestris with much } \\
\text { reduced vigor; } \\
\text { S. columbiana; } \\
\text { P. sandbergii }\end{array}$ \\
\hline $\begin{array}{l}\text { Stavely, Alberta } \\
\quad \text { (lat } 50^{\circ} 12^{\prime} \mathrm{N} \text {, long } \\
113^{\circ} 54^{\prime} \mathrm{W} \text {; elevation } \\
1340 \mathrm{~m} \text { ); established } \\
\text { in } 1949\end{array}$ & $\begin{array}{l}\text { F. campestris; } \\
\text { Danthonia parryi } \\
\text { Scribn. }\end{array}$ & $\begin{array}{l}\text { F. campestris with much } \\
\text { reduced vigor; } \\
\text { Poa spp.; Carex spp.; } \\
\text { F. idahoensis }\end{array}$ \\
\hline
\end{tabular}

Karoly 2004). Recently, Matlaga and Karoly (2004) found no genetic difference between grazed and protected populations of Festuca idaboensis Elmer using ISSR (intersimple sequence repeat) DNA markers. However, a preliminary RAPD (random amplified polymorphic DNA) analysis with F. campestris, which is a much more grazing-sensitive species (Willms et al. 1985), seemed to suggest there were significant changes in gene frequencies due to grazing (W. Willms, unpublished data, 2004).

Populations of F. campestris, although mostly fragmented, are well adapted to the grasslands in western Canada, and regional variants or ecotypes may also exist (Pavlick and Looman 1984). Phenotypic characterization of F. campestris from various sites in Alberta and one site in British Columbia showed that the British Columbia population was phenotypically distinct (May et al. 2003). Although more phenotypic differentiation in this longitudinal range should be determined, analysis of the molecular variability within and between populations from geographically distinct sites can provide evidence of whether or not ecotypic variants have formed. Molecular analysis is free of environmental fluctuations that commonly plague field nursery experiments.

The amplified fragment length polymorphism (AFLP) technique (Vos et al. 1995) is a robust and highly effective method of DNA fingerprinting that can be used to assess genetic variability. This technique has been successfully applied to detect genetic variation in many grass species such as bluebunch wheatgrass (Pseudoroegneria spicata [Pursh] A. Love) (Larson et al. 2000), crested wheatgrass (Agropyron spp. Gaertn.) (Mellish et al. 2002), and little bluestem (Schizachyrium scoparium [Michx.] Nash) (Fu et al. 2004b). Molecular diversity analyses have contributed to the germplasm development for rangeland seeding in sampling diverse germplasm from natural stands (Fu et al. 2004b), selecting representative germplasm for improvement (Phan et al. 2003), and assessing genetic shift in seed increase (Fu et al. 2004a).
It is likely that the genetic impact of long-term grazing on grasses may vary among populations representing different ecotypes from various geographic areas (Milchunas et al. 1988), but previous tests of grazing impacts have been largely conducted on grazed and ungrazed plants sampled from a single population (e.g., Tomás et al. 2000; Matlaga and Karoly 2004). The objective of this study was to assess the genetic diversity of $F$. campestris plants at adjacent grazed and ungrazed areas for 3 populations using AFLP markers.

\section{MATERIALS AND METHODS}

\section{Plant Materials}

Three F. campestris populations with 50- to 70-year exclosures (cattle exclusion paddocks) were selected for this study from Goose Lake and Milroy, British Columbia, and Stavely, Alberta (Table 1). For each population, an ungrazed sample of approximately $40 \mathrm{~F}$. campestris plants was collected within the exclosure in the spring of 2002; a grazed sample of the same size was collected approximately $20 \mathrm{~m}$ away from the exclosure. In either the exclosure or the grazing area, single plants at least $1 \mathrm{~m}$ apart were randomly selected and a plug of tillers of each was collected. Thus, each sampled plant had a history of either longterm protection from grazing or heavy grazing pressure (Table 1).

The plugs of tillers were transported from the field; their leaves were clipped to about $5 \mathrm{~cm}$ above the crown and their tillers separated to produce clones for a common nursery trial. The clipped leaves were double-washed, blotted dry, wrapped in aluminum foil, frozen at $-20^{\circ} \mathrm{C}$, and then freeze-dried. The freeze-dried leaf tissue was shipped to the Genetic Diversity Laboratory of Plant Gene Resources of Canada at Saskatoon for AFLP analysis.

\section{DNA Extraction and AFLP Analysis}

Tissue fragments from the collected leaf tissue were randomly sampled into 96-well plates for DNA extraction. Genomic DNA was extracted from 231 tiller samples representing 2 sample types (grazed and ungrazed) from 3 distinct populations using the DNeasy Plant Mini Kit (Qiagen Inc., Mississauga, ON, Canada). Extracted DNA was quantified by fluorometry using Hoechst 33258 stain (Sigma Chemical Company, St Louis, MO), followed by dilution to $25 \mathrm{ng} \cdot \mu \mathrm{L}^{-1}$ for AFLP analysis.

AFLP analysis was performed using the AFLPTM Analysis System 1 (Life Technologies, Burlington, ON, Canada) following the protocol described by Vos et al. (1995). The protocol included 4 main steps: 1) restriction digestion of $250 \mathrm{ng}$ genomic DNA with EcoRI and MseI restriction enzymes and ligation of adapters to the restriction fragments in order to create primary templates; 2) preamplification of the primary templates with AFLP primers with an additional single nucleotide at the $3^{\prime}$ end; 3 ) selective amplification of the preamplified fragments with $M s e I$ and $\left[\gamma^{33} \mathrm{P}\right]$-labeled EcoRI primers, both having 3 selective nucleotides at the $3^{\prime}$ end; and 4) separation of the amplification products on a $5 \%$ denaturing polyacrylamide gel for 2.5 hours at $90 \mathrm{~W}$. After electrophoresis the gel was transferred to Whatman $3 \mathrm{MM}$ paper, dried on a gel dryer for 2 hours at $80^{\circ} \mathrm{C}$, and exposed to Kodak BIOMAX film at $-80^{\circ} \mathrm{C}$ for 1 to 7 days, depending on the signal intensity. The sizes of 
amplification products were determined by comparison with a 30-330-bp AFLP DNA ladder (Promega, Madison, WI). The polymerase chain reaction profile for step 3 was performed in a PTC-200 DNA Engine thermocycler (MJ Research, Watertown, MA) using the following amplification protocol: a denaturing step of 30 seconds at $94^{\circ} \mathrm{C}$, followed by an annealing step of 30 seconds at $65^{\circ} \mathrm{C}$ and an extension step of 60 seconds at $72^{\circ} \mathrm{C}$. Next, 12 cycles following a touchdown format decreased the annealing temperature by $0.7^{\circ} \mathrm{C}$ after each cycle until a final annealing temperature of $56^{\circ} \mathrm{C}$ was attained. The last cycle was repeated 23 times and was performed using the following profile: $94^{\circ} \mathrm{C}$ for 30 seconds, $56^{\circ} \mathrm{C}$ for 30 seconds, and $72^{\circ} \mathrm{C}$ for 60 seconds.

Ten EcoRI:MseI primer pairs were initially screened on 8 randomly selected samples. The 5 most informative pairs $(\mathrm{E}+\mathrm{AAC} / \mathrm{M}+\mathrm{CAG}, \mathrm{E}+\mathrm{AAG} / \mathrm{M}+\mathrm{CAC}, \mathrm{E}+\mathrm{ACG} / \mathrm{M}+$ CTA, E + AGG/M + CGC, and E + AGG/M + CTC) were selected to genotype all the samples. Efforts were also made with a blind test of 2 randomly selected DNA samples placed in different gels to minimize errors from technique and scoring.

\section{Data Analysis}

For each gel generated from each primer pair, the numbers of observable and monomorphic AFLP bands were counted. Polymorphic AFLP bands with clarity for all the samples were manually scored as 1 (present) or 0 (absent), and these scored bands were assessed for mismatch before being selected for further analysis. The selected bands were first analyzed for the level of polymorphism by counting the number of polymorphic bands and calculating their frequencies with respect to primer pair, population, and sample type. For each site, a $\chi^{2}$ test of significance for the difference in frequency of a polymorphic band between 2 sample types was made, and a heterogeneity $\chi^{2}$ test was applied to all the polymorphic bands. To compare the AFLP variations with respect to grazing history, the numbers of polymorphic bands were plotted in a histogram by their frequency of occurrence in each population.

For each sample type, analysis of molecular variance (AMOVA; Excoffier et al. 1992) was performed using Arlequin version 2.001 (Schneider et al. 2002) to assess AFLP variation across the 3 populations. This analysis not only allows the partition of total AFLP variation into within- and amongpopulation components, but also provides a measure of interpopulation distances (Huff et al. 1998). Significance of resulting variance components and interpopulation distances was tested with 10000 random permutations. To assess the AFLP differences between grazed and nongrazed samples in each population, an AMOVA was also performed. This populationspecific AMOVA analysis not only allows the partition of total AFLP variation into within- and between-sample components from single populations, but also provides tests on the significance of the difference between the 2 samplings of a population with 10000 random permutations.

To assess the genetic relationships of the 3 populations, the interpopulation distance matrices for each sample type were analyzed using NTSYS-pc 2.01 (Rohlf 1997) and clustered with the algorithm of unweighted pair-group methods using arithmetic averages. To assess the associations of AFLP variation with geographical origin and elevation, the interpopulation distance matrices with the corresponding geographical distan-

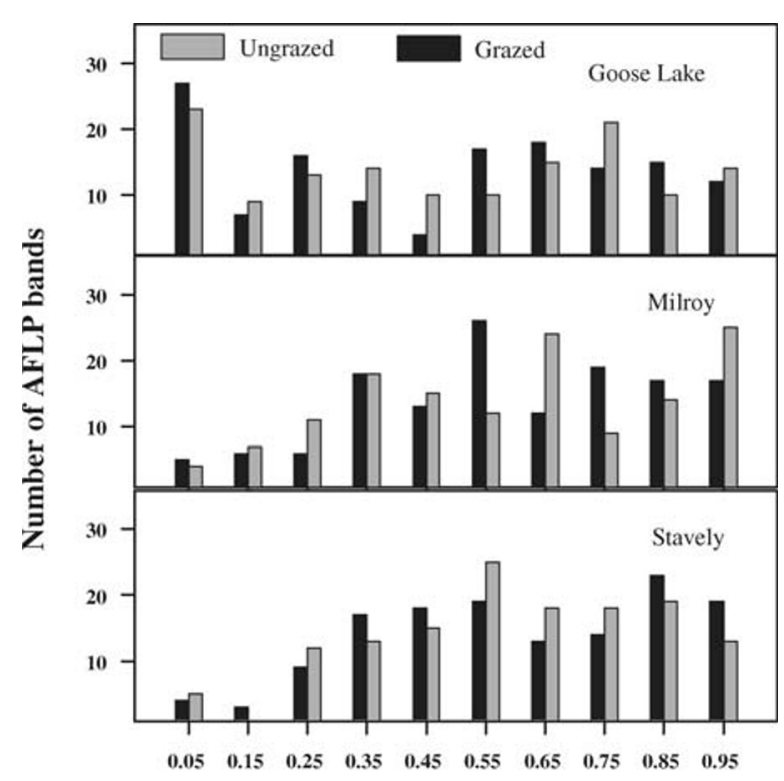

Band frequency in each population

Figure 1. Numbers of polymorphic AFLP bands with respect to their frequencies of occurrence in each population of Festuca campestris Rydb., as reflected in the plants sampled from ungrazed and grazed areas.

ces and elevation differences of their collection sites were also examined for either sample type with the MXCOMP program of NTSYS-pc with 10000 random permutations.

\section{RESULTS AND DISCUSSION}

\section{AFLP Variation}

Five AFLP primer pairs amplified a total of 828 AFLP bands. The number of observable bands per primer pair ranged from 148 to 198 . About $91 \%$ of the observable bands were polymorphic over the samples assayed. This result not only indicates the presence of large AFLP variation in this native grass species but also suggests that this plant is highly outcrossing (Aiken and Darbyshire 1990; Larson et al. 2001a). However, no studies were found regarding the mating system of this species. This high level of polymorphism is compatible with AFLP findings reported for other highly outcrossing grass species such as P. spicata (Larson et al. 2000), Poa spp. (Larson et al. 2001b), Bromus inermis Leyss. and Bromus riparius Rehmann (Ferdinandez and Coulman 2002), Agropyron cristatum (Mellish et al. 2002), Bouteloua gracilis (Willd. Ex Kunth) Lag. ex Griffiths (Fu et al. 2004a), and S. scoparium (Fu et al. 2004b).

Because a majority of the detected amplified polymorphic bands lacked clarity, only 139 scored bands were selected for further analyses. These bands were presumably sampled from the entire fescue genome $(2 n=8 x=56)$, but the exact genomic coverage remains unknown. The frequencies of the selected bands averaged 0.566 (0.126 to 0.966$)$ for the grazed sample and 0.570 (0.108 to 0.973$)$ for the ungrazed sample. The detailed distributions of occurrence frequency for these scored bands are given in Figure 1 with respect to collection site and grazing history. A wide range of band frequencies was 


\section{A: Ungrazed}
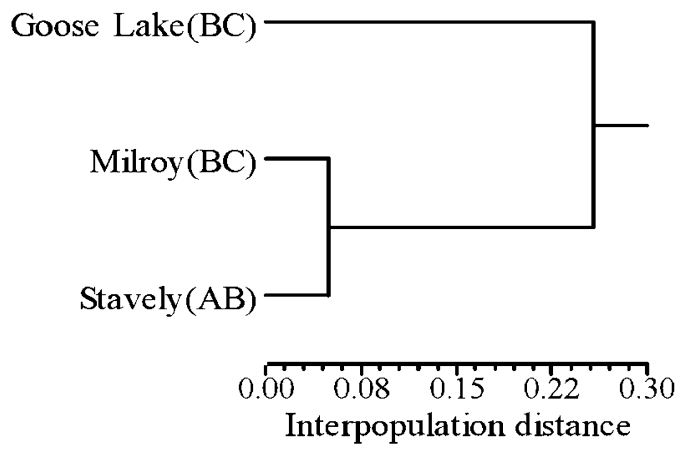

B: Grazed

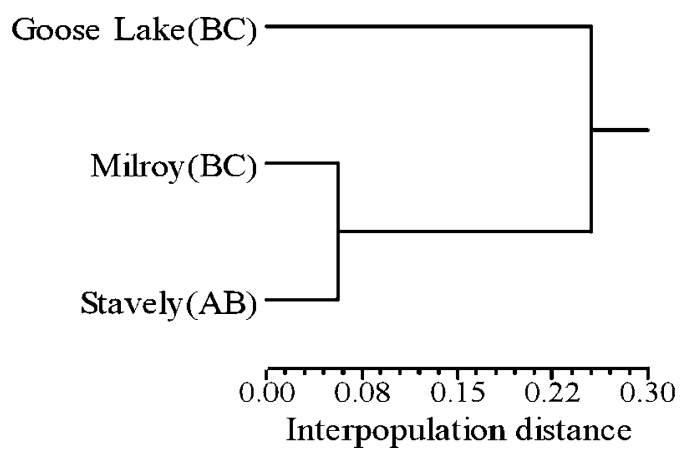

Figure 2. Clustering of the 3 Festuca campestris Rydb. populations based on interpopulation distances obtained from the molecular analysis of variance on the 139 polymorphic AFLP bands, as reflected in the plants sampled from ungrazed $(\mathbf{A})$ and grazed $(\mathbf{B})$ areas.

observed for each site and sample type. Differences in number of AFLP bands between grazed and ungrazed samples appeared to be large for the Goose Lake and Milroy populations, but not for the Stavely population. The mean frequencies of AFLP bands detected from one AFLP primer pair ranged from 0.493 for the primer pair E + AGG/M + CGC to 0.647 for the primer pair $\mathrm{E}+\mathrm{AAG} / \mathrm{M}+\mathrm{CAC}$, indicating the heterogeneity of the genomic regions sampled. These results indicated the AFLP technique was effective in detecting molecular variability in F. campestris.

\section{AFLP Variation Between Grazed and Ungrazed Samples}

With respect to AFLP variation detected by individual primer pairs, there were no obvious differences between 2 sample types in the number of the monomorphic bands observed and the mean frequencies of the scored bands. However, the ungrazed samples appeared to show a wider range of band frequency distribution (0.108 to 0.973 ) than was observed for the grazed samples $(0.126$ to 0.966$)$. This result indicates that the genomic sampling was more or less the same for the 2 sample types. The 2 sample types displayed similar proportions of variation among populations $(19.28 \%$ for the ungrazed sample and $19.71 \%$ for the grazed sample). Comparison of the associations of the 3 populations revealed the same genetic relationships for 2 sample types (Fig. 2A vs. Fig. 2B). These results indicate that the AFLP differences between grazed and ungrazed samples were small, and using one sample instead of the other should have minimal effect on genetic inferences of population relationships.

However, comparisons of the pairwise samples of grazed and ungrazed areas at single sites revealed significant genetic differences in the Goose Lake and Milroy populations, but not in the Stavely population. The grazed sample from Goose Lake, when measured as average pairwise AFLP difference within a sample, displayed less within-sample variation (42.92) than did its contrasting sample (43.68), indicating a negative impact of grazing on the genetic diversity of the grazed population; the grazed sample from Milroy displayed more within-sample variation (49.23) than did its contrasting sample (46.84), suggesting a positive impact of grazing on the genetic diversity of the grazed population. However, the differences residing between the pairwise samples were small; $1.49 \%$ of total AFLP variation for the Goose Lake population and $2.24 \%$ for the Milroy population. Such differences were largely reflected in the heterogeneity of band frequencies, rather than absolute differences in polymorphic bands scored. This was evident when considering the patterns of AFLP variation given in Table 2 and Figure 1. For example, the numbers of polymorphic bands scored were relatively similar for the pairs of sampling at individual sites (Table 2), but the numbers of polymorphic bands displaying higher or lower frequency within the grazed sample than its contrasting ungrazed sample were not compatible at each population (74 vs. 55 for Goose Lake, 80 vs. 58 for Milroy, and 63 vs. 75 for Stavely; Table 2). Such differences occurred for the scored bands of various occurrence frequencies ranging from 0.1 to 0.9 (Fig. 1), indicating the genetic changes were not restricted to a specific type of scored bands such as infrequent or most frequent bands. Specifically, grazing appeared to increase band frequencies at the Goose Lake and Milroy populations, but to decrease band frequencies at the Stavely population (Table 2). Thus, these comparisons revealed different impacts of grazing, even though relatively small, on the genetic diversity of the grazed F. campestris populations, with a negative effect in Goose Lake, a positive effect in Milroy, and no effect in Stavely.

Small genetic divergence among the $F$. campestris plants of the grazed and ungrazed areas may reflect the genetic consequence of intense selection for grazing resistance before the establishment of these exclosures and/or weak selection for grazing resistance after their establishment. It is also possible that the applied AFLP markers may not effectively sample all the chromosomal segments under grazing selection pressure. In this study, only 4 out of 139 AFLP bands displayed significant differences in band frequency between grazed and ungrazed samples in all 3 populations and were likely associated with grazing resistance. They were the 106-pb DNA fragment detected from the primer pair $\mathrm{E}+\mathrm{AAG} / \mathrm{M}+\mathrm{CAC}$, the 98bp and 136-bp fragments from E + ACG/M + CTA, and the 331-bp fragment from $\mathrm{E}+\mathrm{AGG} / \mathrm{M}+\mathrm{CGC}$. Increasing the number of AFLP markers to assay larger $(>200)$ genotypes in both grazed and ungrazed samples may increase the resolution of identifying significant chromosomal segments for grazing resistance. Further study, currently under way, on phenotypic expression of grazing effects using the common garden technique, should also shed some additional insight into these variable grazing effects.

The significant, though small, impacts of grazing in both the Goose Lake and Milroy populations suggest that grazing can 
Table 2. Comparisons of AFLP variability between the Festuca campestris Rydb. samples of protected (P) and grazed (G) areas from the Goose Lake, Milroy, and Stavely populations.

\begin{tabular}{|c|c|c|c|c|c|c|}
\hline \multirow[b]{2}{*}{ Population } & \multicolumn{2}{|c|}{ Goose Lake } & \multicolumn{2}{|c|}{ Milroy } & \multicolumn{2}{|c|}{ Stavely } \\
\hline & $P$ & G & $P$ & G & $P$ & G \\
\hline Effective sample size & 40 & 35 & 39 & 40 & 40 & 37 \\
\hline Monomorphic/total bands observed (\%) & 11.0 & 11.4 & 10.9 & 11.5 & 11.0 & 10.3 \\
\hline No. of polymorphic bands scored & 125 & 126 & 138 & 130 & 134 & 139 \\
\hline Mean frequency of scored bands & 0.506 & 0.504 & 0.587 & 0.578 & 0.605 & 0.591 \\
\hline Maximum frequency of scored bands & 0.975 & 0.971 & 0.974 & 0.975 & 0.975 & 0.973 \\
\hline Minimum frequency of scored bands & 0.025 & 0.029 & 0.026 & 0.075 & 0.025 & 0.027 \\
\hline No. of polymorphic bands lost (and fixed) ${ }^{1}$ & $4(1)$ & $3(2)$ & $0(1)$ & $1(9)$ & $1(3)$ & $0(1)$ \\
\hline No. of frequency-reduced bands ${ }^{2}$ & 55 & & 58 & & 75 & \\
\hline No. of frequency-increased bands ${ }^{2}$ & 74 & & 80 & & 63 & \\
\hline No. of significant single-band $\chi^{2}$-tests ${ }^{3}$ & $8+7$ & & $9+13$ & & $4+0$ & \\
\hline Heterogeneity $\chi^{2}$-test value for all bands & $200 * * *$ & & $277 * * *$ & & $147^{\mathrm{ns}}$ & \\
\hline Variation within each sample ${ }^{4}$ & 42.92 & 43.68 & 49.23 & 46.84 & 49.87 & 49.96 \\
\hline Variation between samples $(\%)^{4}$ & $1.49 * * *$ & & $2.24 * * *$ & & $0.01^{\mathrm{ns}}$ & \\
\hline
\end{tabular}

${ }^{1}$ The number of polymorphic bands lost (and fixed) in the sample relative to its contrasting sample.

${ }^{2}$ The number of bands displaying the reduced or increased frequencies in the sample relative to its contrasting sample.

${ }^{3}$ The number of significant $\chi^{2}$-tests at $P<0.05=$ the sum of the numbers of significant $\chi^{2}$-tests for both frequency-reduced and frequency-increased bands.

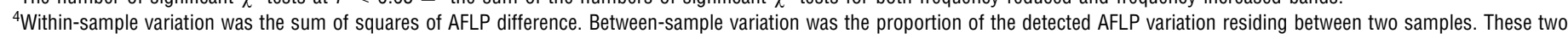
variation components were obtained from the molecular analysis of variance (Excoffier et al. 1992).

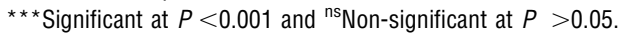

differentially affect the genetic diversity of the grazed populations of a perennial grass. Inconsistent effects of grazing on genetics of populations of other grass species have also been reported (Tomás et al. 2000; Matlaga and Karoly 2004). Our findings lend some support for the theoretical prediction by Michunas et al. (1988) that grazing impacts on the genetic diversity of a grass may vary among populations or ecotypes. Further testing of additional F. campestris populations with and without a history of grazing would be desirable, but the availability of additional $F$. campestris populations with longterm exclosures is scarce (McLean and Tisdale 1972). Also, the hypothesis of variable responses to grazing history among populations should be tested for other native grass species.

\section{AFLP Variation Among Populations}

Genetic variation and differentiation of the 3 F. campestris populations was also analyzed using pooled samples of grazed and ungrazed areas for each population, because the AFLP differences between 2 sample types were small. The results obtained were similar to those for the samples of either grazed or ungrazed areas. To simplify interpretation, only the results from the ungrazed sample are reported here. The Stavely sample had the lowest proportion of monomorphic bands $(10.3 \%)$, followed by the Goose Lake $(11.4 \%)$ and Milroy $(11.5 \%)$ samples. The Stavely sample had 139 bands, Milroy 130, and Goose Lake 126 (Table 2). With band frequencies ranging from 0.027 to 0.973 , the Stavely sample had a wider range of AFLP variation than did the other 2 samples. Based on AMOVA, the Stavely sample displayed the highest withinpopulation variation (49.96), followed by the Milroy (46.84) and Goose Lake (43.68) samples (Table 2).

Partitioning the total AFLP variation into within- and among-population components by AMOVA showed that $80.7 \%$ of the total variation was present within the ungrazed samples, with the remaining $19.3 \%$ among the 3 populations. Also, the among-population variation was greater than zero $(P<0.0001)$ based on 10000 random permutations. These results not only indicate the existence of differential genotypes in these populations, but also suggest that $F$. campestris is highly outcrossing. The largest interpopulation distance was observed between the Goose Lake population and those of Milroy (0.262) and Stavely (0.252), while the difference between Milroy and Stavely was much smaller (0.049) (Fig. 2A). The groupings in Figure $2 \mathrm{~A}$ may be associated with geographical origin $(r=0.91)$ and elevation $(r=0.82)$. However, these associations were not statistically significant $(P>0.05)$ when assessed by a Mantel test due to the small number of sites (3) surveyed. The relatively large difference between the Goose Lake and Stavely populations support earlier morphological indications of a different ecotype in the Kamloops area (Pavlick and Looman 1984; May et al. 2003). The Milroy and Stavely populations are separated by the Rocky Mountains. However, there is a corridor for gene flow through the Crowsnest Pass; F. campestris occurs throughout this corridor. On the other hand, the Goose Lake population is separated from the Stavely population by 3 major mountain ranges, and consequently fewer opportunities exist for gene flow between these populations. Analysis of more populations could help to determine the genetic divergence of $F$. campestris over its geographic range.

\section{MANAGEMENT IMPLICATIONS}

To develop diverse germplasm for seeding rangelands, sampling across geographic space is likely more important than sampling over diverse grazing histories. Long-term grazing accounted for relatively small (up to $2 \%$ ) differences in AFLP variation, even with a variable direction of genetic shift within each population. 
Thus, selection of $F$. campestris in either grazed or ungrazed areas should capture compatible levels of AFLP variation and sampling of more populations is more feasible. Relatively large between-population variation $(20 \%$ of the total AFLP variation) indicates genetic distinctness between distant populations should also be considered when collecting germplasm for development of $F$. campestris seeds for reclamation. In particular, it appears that populations on the interior plateau of British Columbia may differ from those in the Rocky Mountain foothills.

\section{ACKNOWLEDGMENTS}

The authors would like to thank Harriet Douwes, Barbara Brooke, and Jay Finstad for assistance in plant and tissue collections; Gregory W. Peterson and Angela Taylor for technical assistance on the AFLP analysis; and John Willmshurst, Anh Phan, and 2 anonymous reviewers for their valuable comments on the early version of the manuscript.

\section{LITERATURE CITED}

Aiken, S. G., and S. J. DarbyshiRe. 1990. Fescue grasses of Canada. Ottawa, Ontario, Canada: Agriculture Canada. Publication 1844/E. 113 p.

Caldwell, M. M., J. H. Richards, D. A. Johnson, R. S. Nowak, and R. S. Dzurec. 1981 Coping with herbivory: photosynthetic capacity and resource allocation in two semiarid Agropyron bunchgrasses. Oecologia 50:14-24.

Carman, J. G., and D. D. BRISKE. 1985. Morphological and allozymic variation between long-term grazed and non-grazed populations of the bunchgrass Schizachyrium scoparium var. frequens. Oecologia 66:332-337.

Excoffier, L., P. E. Smouse, AND J. M. QuatTRo. 1992. Analysis of molecular variance inferred from metric distances among DNA haplotypes: application to human mitochondrial DNA restriction data. Genetics 131:479-491.

Ferdinandez, Y. S. N., and B. E. Coulman. 2002. Evaluating genetic variation and relationships among two bromegrass species and their hybrid using RAPD and AFLP markers. Euphytica 125:281-291.

Fu, Y. B., Y. S. N. Ferdinandez, A. T. Phan, B. Coulman, and K. W. Richards. 2004a. AFLP variation in four blue grama seed sources. Crop Science 44:283-288.

Fu, Y. B., A. T. Phan, B. Coulman, and K. W. Richards. 2004b. Genetic diversity in natural populations and corresponding seed collections of little bluestem as revealed by AFLP markers. Crop Science 44:2254-2260.

Hodgkinson, K. C., AND 0. B. Williams. 1983. Adaptation to grazing in forage plants. In: J. G. Mclvor and R. A. Bray [EDS.]. Genetic resources of forage plants. East Melbourne, Australia: CSIR0. p 85-100.

Huff, D. R., J. A. Quinn, B. Higgins, and A. J. Palazzo. 1998. Random amplified polymorphic DNA (RAPD) variation among native little bluestem [Schizachy- rium scoparium (Michx.) Nash] populations from sites of high and low fertility in forest and grassland biomes. Molecular Ecology 7:1591-1597.

KalKNeR, L. K., and M. D. Casler. 2000. Genetic shift in smooth bromegrass under grazing: changes in nutritional value and preference for surviving vs. original genotypes. Grass and Forage Science 55:351-360.

Larson, S. R., E. Cartier, C. L. McCracken, and D. Dyer. 2001a. Mode of reproduction and amplified fragment length polymorphism variation in purple needlegrass (Nassella pulchra): utilization of natural germplasm sources. Molecular Ecology 10:1165-1177.

Larson, S. R., T. A. Jones, Z. M. Hu, C. L. McCracken, and A. Palazzo. 2000. Genetic diversity of bluebunch wheatgrass cultivars and a mulitiple-origin polycross. Crop Science 40:1142-1147.

Larson, S. R., B. L. Waldron, S. B. Monsen, L. St. John, A. J. Palazzo, C. L. McCracken, AND R. D. HARRISON. 2001b. AFLP variation in agamospermous and dioecious bluegrasses of western North America. Crop Science 41:1300-1305.

MatlaGa, D., AND K. Karoly. 2004. Long-term grazing effects on genetic variation in Idaho fescue. Journal of Range Management 57:275-279.

MaY K. W., W. D. Willms, M. L. ZhaO, AND T. J. LYSYK. 2003. An assessment of variation in foothills rough fescue [Festuca campestris (Rydb.)] in southern Alberta. Canadian Journal Plant Science 83:541-550.

McLean, A., ANd E. W. TISDALE. 1972. Recovery rate of depleted range sites under protection from grazing. Journal of Range Management 25:178-184.

Mellish, A., B. Coulman, and Y. Ferdinandez. 2002. Genetic relationships among selected crested wheatgrass cultivars and species determined on the basis of AFLP markers. Crop Science 42:1662-1668.

Milchunas, D. G., O. E. Sala, and W. K. LaUenRoth. 1988. A generalized model of the effects of grazing by large herbivores on grassland community structure. American Naturalist 132:87-106.

Pavlick, L. E., AND J. Looman. 1984. Taxonomy and nomenclature of rough fescues, Festuca altaica, F. campestris, and F. hallii in Canada and the adjacent part of the United States. Canadian Journal of Botany 62:1739-1749.

Phan, A. T., Y. B. Fu, AND S. R. Smith, Jr. 2003. RAPD variations in selected and unselected blue grama populations. Crop Science 43:1852-1857.

RoHLF, F. L. 1997. NTSYS-pc: Numerical taxonomy and multivariate analysis system. Setauket, NY: Exeter Publishing, Ltd.

SCHNEIDER, S., D. RoESSLI, AND L. EXCOFfIER. 2002. Arlequin ver. 2.001: A software for population genetics data analysis. Geneva, Switzerland: Genetics and Biometry Laboratory, University of Geneva. Available at http://lgb.unige.ch/arlequin/ software. Accessed 21 July 2005.

Tomás, M. A., A. D. Carrera, and M. Póverene. 2000. Is there any genetic differentiation among populations of Piptochaetium napostaense (Speg.) Hack (Poaceae) with different grazing histories? Plant Ecology 147:227-235.

Vos, P., R. Hogers, M. Bleeker, M. Reijans, T. van De Lee, M. Hornes, A. Frijters, J. Peleman, M. Kuiper, and M. Zabeau. 1995. AFLP: a new technique for DNA fingerprinting. Nucleic Acids Research 23:4407-4414.

Willms, W. D, S. Smoliak, and J. F. Dormaar. 1985. Effects of stocking rate on rough fescue grassland vegetation. Journal of Range Management 38:220-225. 